\title{
Hypopharyngeal Cancer Pathologic Regional Lymph Nodes TNM Finding v6
}

National Cancer Institute

\section{Source}

National Cancer Institute. Hypopharyngeal Cancer Pathologic Regional Lymph Nodes

TNM Finding v6. NCI Thesaurus. Code C64581.

hypopharyngeal cancer, following the rules of the TNM classification system as they pertain to staging of regional lymph nodes. 